\title{
The Evaluation of Internal Quality Assurance System Implementation Program at Bali School Model In 2018
}

\author{
Ni Made Suciani ${ }^{1}$, Mala Sondang Silitonga ${ }^{2}$, Madrikan $^{3}$ \\ ${ }^{1}$ Lembaga Penjaminan Mutu Pendidikan Bali, \\ 2STIA LAN Jakarta \\ ${ }^{3}$ Lembaga Penjaminan Mutu Pendidikan Jawa Timur \\ e-mail: sucilpmpbali@gmail.com
}

\begin{abstract}
This study aims to measure the effectiveness of the implementation of SPMI in the LPMP Bali school model using the CIPP model (context, input, process, product). The study began with the measurement of the level of conformity between the results of the initial school evaluation model and the achievement of the 2017 school model SNP quality report. The results of the initial evaluation on 11 target schools showed that the level of achievement of the initial evaluation of the SPMI school in 2018 was not comparable with the SNP school quality report card for SPMI in Bali Province in 2017. This is indicated by insignificant correlation values. This means that the model school has not been able to run SPMI properly, even though the model school program at the school has been running in the third year. Furthermore, from these results, an appropriate mentoring strategy was made in accordance with the weaknesses of each school and six months of assistance was provided for the school model. The results of the final evaluation after assistance were divided into five categories, namely very effective, effective, quite effective, ineffective and very ineffective. Evaluation in the context component shows effective results, the input component results are very effective, while in the mapping process, quality planning, and implementation of effective quality fulfillment, monitoring and evaluation is quite effective. The results component also shows the average achievement in the effective category. The recommendation given from the results of this study is that it is necessary to develop appropriate assistance strategies according to the needs of each school based on the results of the initial school evaluation, and need to carry out measurements of the results of the final evaluation after being given assistance.
\end{abstract}

Keywords: Internal Quality Assurance System, school model, context, input, process, product

\section{Introduction}

This research was a step towards schools quality improvement and development, since as stated by De Grauwe\& Naidoo (2004), evaluating school quality involves assessing all aspects of the school and its impact on students to identify the quality of education at schools. Policy makers and researchers emphasize the need for school evaluations regarding quality control, quality monitoring, quality assurance and quality development. Furthermore, school evaluation includes administrative, pedagogical and managerial improvements. In many countries, the evaluation was more important to students and teacher than schools. Similarly, the Indonesian Ministry of Education and Culture through the Directorate of Primary and Secondary Education always develops programs aimed at allowing schools to implement their own quality education internally.

One of the programs was the implementation of Internal Quality Assurance System (locally known as Sistem Penjaminan Mutu Internal or SPMI) which was escorted by the Education Quality Assurance Agency as the technical implementation unit of the Ministry of Education and Culture. This model was called SPMI program since 2016. During the process of these policies and programs, there are various obstacles and challenges that arise in its implementation. The main challenge relates to stakeholder understanding of internal quality Assurance System (SPMI) and its implementation at the education unit level. The results of the study between the achievements of the initial evaluation and the achievement of the school quality report cards showed insignificant correlation. The results showed in the following table. 
Table 1. Relationship between the results of the initial evaluation of the school model SPMI and Education National Standard (SNP) achievements on the 2017 quality school report card

\begin{tabular}{|c|c|c|c|c|}
\hline \multirow{2}{*}{ No } & \multirow{2}{*}{ School Names } & \multirow{2}{*}{ SPMI Results } & \multicolumn{2}{|c|}{ SNP achievements } \\
\hline & & & $1-7$ & $1-100$ \\
\hline 1 & SDN 2 Musi & 56,25 & 5,43 & 77,59 \\
\hline 2 & SMPN 2 Singaraja & 68,75 & 5,81 & 82,95 \\
\hline 3 & SDN 3 Bubunan & 56,25 & 5,99 & 85,57 \\
\hline 4 & SMK Tri Atmajaya & 51,25 & 5,39 & 77,02 \\
\hline 5 & SMPN 2 Mengwi & 68,75 & 5,73 & 81,80 \\
\hline 6 & SDN 2 Kapal & 65,00 & 5,80 & 82,86 \\
\hline 7 & SDN 17 DauhPuri & 61,25 & 5,17 & 73,86 \\
\hline 8 & SMPN 1 Mengwi & 73,75 & 5,67 & 80,96 \\
\hline 9 & SD 4 Jimbaran & 60,00 & 5,91 & 84,43 \\
\hline 10 & SMPN 3 Denpasar & 71,25 & 5,61 & 80,18 \\
\hline 11 & SMAN 1 Mengwi & 56,25 & 5,81 & 83,00 \\
\hline \multicolumn{2}{|r|}{ Average } & 62,61 & 5,67 & 80,93 \\
\hline & Correlation & \multicolumn{3}{|c|}{0,1398} \\
\hline
\end{tabular}

The result of the Spearman Rank correlation was 0.1398 . The result was compared with the results of $r$ table at a significance level of $5 \%$ with eleven samples. From the table rho was equal to 0.523. Thus the correlation was not significant. Both of these initial analyzes indicate that the school has not been able to conduct a self-evaluation, since the Education Quality Mapping instrument was not good and has not been in accordance with the reality that occurred at schools.

In addition to referring to real data as described, this research was conducted also because of the weight of the challenges for Bali Quality Assurance Institution or LPMP Bali in assisting schools internal quality assurance system (SPMI). Limited examples, instructions, and technical guidelines for implementing SPMI made this mentoring process less focused, less effective and less efficient to achieved goals. The evaluation covers four components: context, input, process and results. The formulation of the problem in this study was: What are the results of the implementation of internal quality assurance system (SPMI) in the 2018 if viewed from the aspect of context, input, process and results?

\section{Method}

This research includes evaluation research using the CIPP model (context, input, process, and product). This research was conducted at 170 schools under the guidance of Bali Quality Assurance Institution (LPMP Bali). Out of 170 schools, random sampling was conducted in coaching 13 companion teams. Each companion team received around 11 schools. The conceptual framework of this research can be explained in the following figure. 


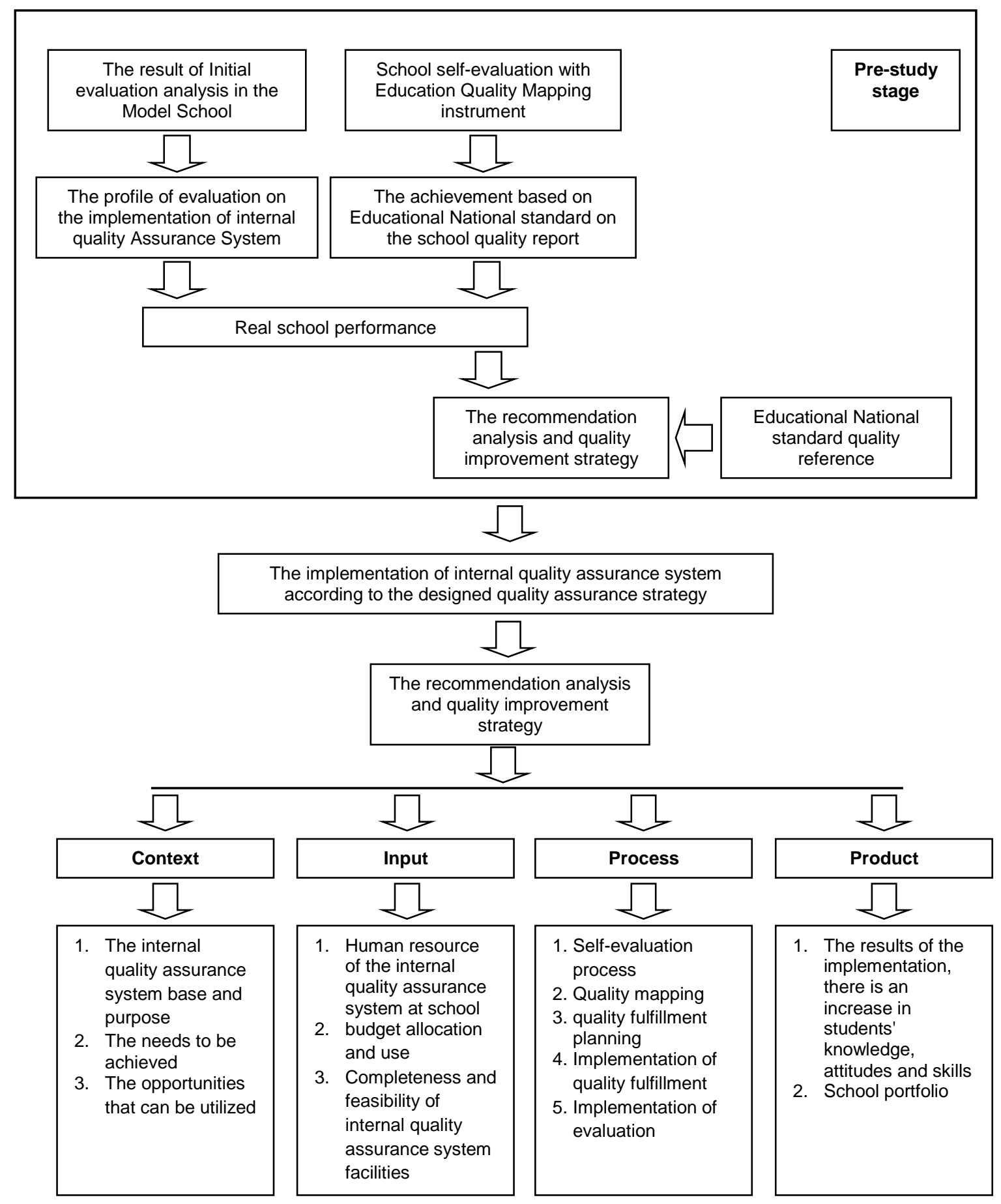

Figure 1. Research Conceptual Framework

According to Stufflebeam (2002b), evaluation is defined as an assessment of needs, problems, opportunities and problems that can be addressed in a particular environment. For this study, the context was evaluated through document analysis which revealed that the main purpose of the internal quality assurance implementation (SPMI) implementation is to enable the education quality assurance cycle and later establish quality culture at their schools. Stufflebeam (2002) explains that the evaluation of input includes evaluation on available resources to achieve goals and meet needs. Furthermore Stuffelbeam, 1971) explains that the basic purpose of process evaluation was to provide descriptions related to 
all activities in the program. Product evaluation assesses results and outputs, either short or long term, international or unintentional, which does not only track but also focus on whether meeting the goals or not (Stufflebeam, 2003).

Table 2. School data

\begin{tabular}{|c|c|c|c|c|}
\hline No & School Names & School Addresses & School Principals & $\begin{array}{l}\text { Supervisor } \\
\text { Couch }\end{array}$ \\
\hline 1 & SD Negeri 2 Musi & $\begin{array}{l}\text { Desa Musi, Kec. } \\
\text { Gerokgak, Kab. } \\
\text { Buleleng. }\end{array}$ & I Putu Arsana, S.Pd. & $\begin{array}{l}\text { I GustiPutuSuratika, } \\
\text { S.Pd.,M.Pd. }\end{array}$ \\
\hline 2 & $\begin{array}{l}\text { SMP Negeri } 2 \\
\text { Singaraja }\end{array}$ & $\begin{array}{l}\text { Jalan Sudirman No. } 78 \\
\text { SIngaraja }\end{array}$ & $\begin{array}{l}\text { I Nyoman Purnayasa, } \\
\text { S.Pd.,MM. }\end{array}$ & $\begin{array}{l}\text { Drs. I GedeDuniawan, } \\
\text { M.Pd. }\end{array}$ \\
\hline 3 & $\begin{array}{l}\text { SD Negeri } 3 \\
\text { Bubunan }\end{array}$ & $\begin{array}{l}\text { Jalan Pemuda Desa } \\
\text { Bubunan Kecamatan } \\
\text { Seririt }\end{array}$ & Ni Made Maharti, S.Pd. & Drs. I KetutDarmawan \\
\hline 4 & $\begin{array}{l}\text { SMK Pariwisata } \\
\text { Tri Atmajaya }\end{array}$ & $\begin{array}{l}\text { Jalan Raya Singaraja } \\
\text { Seririt, Desa Anturan, } \\
\text { Kecamatan Buleleng } \\
\text { Kabupaten Buleleng }\end{array}$ & $\begin{array}{l}\text { A.A.A. Mirah Hartaningrum, } \\
\text { S.Pd. }\end{array}$ & $\begin{array}{l}\text { Drs. PutuDarmasuita, } \\
\text { M.Pd. }\end{array}$ \\
\hline 5 & $\begin{array}{l}\text { SMP Negeri } 2 \\
\text { Mengwi }\end{array}$ & $\begin{array}{l}\text { Br. Tegalsaat Kapal, } \\
\text { Mengwi, Badung }\end{array}$ & Drs. I Ketut Suanda, M.Si. & $\begin{array}{l}\text { Drs. I NyomanSukajaya, } \\
\text { MM. }\end{array}$ \\
\hline 6 & SD Negeri 2 Kapal & $\begin{array}{l}\text { Br. Tambak Sari, } \\
\text { Kapal, Mengwi Badung }\end{array}$ & Drs. I Made Suparna & $\begin{array}{l}\text { Ni WayanKerti, } \\
\text { S.Pd.,M.Pd. }\end{array}$ \\
\hline 7 & $\begin{array}{l}\text { SD Negeri } 17 \\
\text { DauhPuri }\end{array}$ & $\begin{array}{l}\text { Jl. Kahuripan No. } 3 \\
\text { Denpasar }\end{array}$ & I W.Heru Sanjaya, S.Pd. & $\begin{array}{l}\text { Dra. NengahWidnyani, } \\
\text { MM. }\end{array}$ \\
\hline 8 & $\begin{array}{l}\text { SMP Negeri } 1 \\
\text { Mengwi }\end{array}$ & $\begin{array}{l}\text { Jalan Danau Batur } \\
\text { Mengwi, Badung }\end{array}$ & $\begin{array}{l}\text { Drs. I Ketut Paramartha, S.Pd, } \\
\text { MM }\end{array}$ & $\begin{array}{l}\text { Drs. I NyomanSukajaya, } \\
\text { MM. }\end{array}$ \\
\hline 9 & $\begin{array}{l}\text { SD Negeri } 4 \\
\text { Jimbaran }\end{array}$ & $\begin{array}{l}\text { Jalan Raya Uluwatu } \\
\text { Jimbaran }\end{array}$ & Ni Wayan Losni, S.Pd.,M.Pd. & $\begin{array}{l}\text { Putu Witarti Wahyuni, } \\
\text { SH.,M.Pd. }\end{array}$ \\
\hline 10 & $\begin{array}{l}\text { SMP Negeri } 3 \\
\text { Denpasar }\end{array}$ & $\begin{array}{l}\text { Jalan Jepun, N0.5 } \\
\text { Denpasr }\end{array}$ & $\begin{array}{l}\text { I Wayan Murdana, } \\
\text { S.Pd.,M.Pd. }\end{array}$ & $\begin{array}{l}\text { Titik Sri Widayati, } \\
\text { S.Pd.,M.Pd. }\end{array}$ \\
\hline 11 & $\begin{array}{l}\text { SMA Negeri } 1 \\
\text { Mengwi }\end{array}$ & $\begin{array}{l}\text { Jalan Gunung Agung } \\
\text { No. } 3 \text { Mengwi }\end{array}$ & $\begin{array}{l}\text { Ni Luh Made Ratna Agustini, } \\
\text { S.Pd.,M.Pd. }\end{array}$ & $\begin{array}{l}\text { Drs. I } \\
\text { NyomanSumertha, } \\
\text { M.Pd. }\end{array}$ \\
\hline
\end{tabular}

The selection of informants was done purposively, based on the aims and objectives of the study. The instruments used in this study were questionnaire, observation and tests. The supplementary data in this research were the result of documentation and interview. The interviews were conducted with school principals, internal quality assurance system (SPMI) leaders, SPMI members, educators, education staff, educators and committee members or representatives of parents. The instruments used in this study were divided into two parts, 1) pre-research instruments (preliminary study); 2) evaluation instrument for implementation results consisting of instruments of context, input, process and product.

To determine the level of results of this evaluation, the conversion formula used the ideal average and ideal standard deviation. The conversion in question was the result of evaluation data on a scale of 100 which was converted to 5 scales with the specified qualitative level.

Table 3. Conversion table achievement results evaluation of the implementation of the model school SPMI

\begin{tabular}{cccc}
\hline No & Formula & Scores & Qualification \\
\hline 1 & $0-\mathrm{Mi}-1,5 \mathrm{SDi}$ & $0-24$ & Very Low \\
2 & $\mathrm{Mi}-1,5 \mathrm{SDi}-\mathrm{Mi}-0,5 \mathrm{SDi}$ & $25-61$ & Low \\
3 & $\mathrm{Mi}-0,5 \mathrm{SDi}-\mathrm{Mi}+0,5 \mathrm{SDi}$ & $62-79$ & Average \\
4 & $\mathrm{Mi}+0,5 \mathrm{SDi}-\mathrm{Mi}+1,5 \mathrm{SDi}$ & $80-96$ & High \\
5 & $\mathrm{Mi}+1,5 \mathrm{SDi}-100$ & $97-100$ & Very High \\
\hline
\end{tabular}


Information

$\mathrm{Mi}=$ ideal mean obtained from reducing the maximum score with the minimum score obtained. In this case the maximum score was 100 and the minimum score was $30(100-30=70)$

$\mathrm{SDi}=$ ideal standard deviation, which was computed with: $1 / 4 \times \mathrm{Mi}=1 / 4 \times 70=17.5$.

\section{Results and Discussion}

After carrying out the assistance of the implementation of internal quality assurance system or SPMI based on the designed strategy, the next step was to conduct a final evaluation by using instruments on the context, input, process and product. The results obtained can be seen in Table 4.

Table 4. Results of the final evaluation results on the components of the context, inputs, processes and products

\begin{tabular}{|c|c|c|c|c|c|c|c|c|c|c|c|}
\hline \multirow[b]{2}{*}{ NO } & \multirow[b]{2}{*}{ SEKOLAH } & \multirow[b]{2}{*}{ KONTEKS } & \multirow[b]{2}{*}{ INPUT } & \multicolumn{4}{|c|}{ PROSES } & \multicolumn{4}{|c|}{ PRODUK } \\
\hline & & & & $\begin{array}{l}\text { PEME- } \\
\text { TAAN }\end{array}$ & $\begin{array}{c}\text { PERENCA- } \\
\text { NAAN } \\
\text { MUTU }\end{array}$ & \begin{tabular}{|c|} 
PELAKSA- \\
NAAN \\
PEMENU- \\
HAN MUTU
\end{tabular} & MONEV & $\begin{array}{l}\text { PARTISI- } \\
\text { PASI } \\
\text { MASYA- } \\
\text { RAKAT } \\
\end{array}$ & $\begin{array}{c}\text { PARTISI- } \\
\text { PASI } \\
\text { WARGA } \\
\text { SEKOLAH }\end{array}$ & $\begin{array}{l}\text { KOMPE- } \\
\text { TENSI } \\
\text { PTK }\end{array}$ & $\begin{array}{c}\text { MUTU } \\
\text { SEKOLAH }\end{array}$ \\
\hline 1 & SDN 2 Musi & 71,43 & 85,71 & 85,71 & 85,71 & 85,71 & 71,43 & 57,14 & 80,00 & 60,00 & 66,67 \\
\hline 2 & SMPN 2 Singaraja & 85,71 & 100,00 & 85,71 & 85,71 & 85,71 & 71,43 & 71,43 & 80,00 & 80,00 & 100,00 \\
\hline 3 & SDN 3 Bubunan & 85,71 & 85,71 & 85,71 & 85,71 & 100,00 & 85,71 & 57,14 & 80,00 & 60,00 & 66,67 \\
\hline 4 & SMK Tri Atmajaya & 100,00 & 100,00 & 100,00 & 100,00 & 100,00 & 85,71 & 85,71 & 80,00 & 80,00 & 100,00 \\
\hline 5 & SMPN 2 Mengwi & 85,71 & 100,00 & 85,71 & 85,71 & 85,71 & 71,43 & 71,43 & 80,00 & 60,00 & 66,67 \\
\hline 6 & SDN 2 Kapal & 85,71 & 85,71 & 85,71 & 85,71 & 85,71 & 71,43 & 57,14 & 80,00 & 60,00 & 66,67 \\
\hline 7 & SDN 17 Dauh Puri & 100,00 & 100,00 & 100,00 & 100,00 & 100,00 & 85,71 & 71,43 & 80,00 & 80,00 & 66,67 \\
\hline 8 & SMPN 1 Mengwi & 100,00 & 100,00 & 100,00 & 100,00 & 100,00 & 85,71 & 85,71 & 80,00 & 100,00 & 66,67 \\
\hline 9 & SD 4 Jimbaran & 100,00 & 100,00 & 100,00 & 100,00 & 85,71 & 71,43 & 57,14 & 80,00 & 80,00 & 100,00 \\
\hline 10 & SMPN 3 Denpasar & 85,71 & 100,00 & 85,71 & 85,71 & 85,71 & 71,43 & 71,43 & 80,00 & 60,00 & 66,67 \\
\hline 11 & SMAN 1 Mengwi & 85,71 & 100,00 & 100,00 & 85,71 & 100,00 & 85,71 & 71,43 & 80,00 & 60,00 & 66,67 \\
\hline & RERATA & 89,61 & 96,10 & 92,21 & 90,91 & 92,21 & 77,92 & 68,83 & 80,00 & 70,91 & 75,76 \\
\hline
\end{tabular}

Source: results of analysis from CIPP instruments

The average outcomes of the context evaluation result in the effective category. Three schools have achieved 100. These results obtained from conducting a survey of people understanding about the importance of internal quality Assurance System (SPMI) for them. Their awareness of the importance of SPMI had grown since the administration of $S P M I$ socialization in the first stage. Their commitment to apply SPMI could be seen from the signing of quality commitments in large posters that affixed to strategic locations. Almost all school residents had understood what needs to be fulfilled and take advantage of opportunities to improve the quality of their schools. The interview data from the teachers showed that they were very happy and understood the importance of SPMI for their school. They also immediately formed a school quality assurance team and made the organizational structure and description and made quality commitments. Quality commitment not only in the form of administration but also in the form of performance when mentoring, as evidenced by the existence of the learning process, namely discussion and presentation from the teachers in stage 2 and so on.

In input evaluation, the research findings showed that the supervisor was always present at the meeting. Their presence was important as they can figure out what they have to do after the assistance so they can assist the school independently in efforts to fulfill quality. Likewise with the school quality assurance team, the academic and technical teams worked according to the main tasks and functions as stated in the employment contract and mentoring work reference. The use of budget in fulfilling quality could also be budgeted from their School Operational Assistance funds. The results of the input evaluation indicated that the average evaluation result in the input component is in effective category. From the acquisition, each showed that only 3 schools that did not show a score of 100 , meanwhile the rest have achieved a perfect score of 100 . The three schools actually had shown good 
inputs but had not had a complete facilities and infrastructure, such as libraries and practicum equipment for students. Various studies showed that the main purpose of input evaluation is to assess and identify different program strategies to achieve different goals and to provide information that helps the use of certain strategies. Because it was necessary to focus on personnel, resources, procedures and decisions that determine new goals, the next step is to ask how goals can be obtained effectively and efficiently (Stufflebeam, 1969).

In the third evaluation, namely the evaluation of processes related to school evaluation, process evaluation refers to the quality assurance cycle, started from mapping quality, fulfillment planning quality, implementation of quality fulfillment and evaluation monitoring. As displayed in Table 7 , the research findings showed that the average achievement component of this process had been classified as effective, only in the component of monitoring and evaluation which still quite effective. For the process component, all schools had done the preparation of quality mapping results in the form of school profiles. However, their school profile results had not been optimal yet. Regarding the involvement of education stakeholders, almost all schools had not involved Higher Education and Business and Industrial company, except Tri Atma Jaya Vocational School which had involved business and industrial company (locally known as DUDI). But for their next activity they had planned to explore and establish cooperation with business and industrial company. All schools had carried out an analysis of strengths, weaknesses, opportunities and threats for each standard and identified problems that need to be corrected. All schools also determined problems and sought root causes for recommendations.

In evaluating the process of establishing a plan for fulfilling quality, the school referred to recommendations made from the mapping. Furthermore, they determine the volume of activities, resource requirements, quality assurance planning documents in the form of Work Plan and Requirement (RKS) or School Activity and Budget Plans (RKAS), and involve supervisors, principals, teachers, students, school committees, education staff, companies, business and industrial partners and local governments in planning quality fulfillment. This had been done by all model schools, except that the level of achievement varied depending on resources and school management.

In evaluating the implementation of quality fulfillment, all schools had been able to determine the responsibility of the activities, the time frame for implementing the activities and identifying the types of stakeholders involved. In addition, in general, all schools had been able to compile documents on the implementation of quality fulfillment because they have been guided in making reports on activities by the Bali Quality Assurance Institution(LPMP Bali) technical team. In addition schools had also been able to determine the priority scale in the implementation of quality-based fulfillment, availability of resources, level of fulfillment needs, time period needed, and budgetary needs. In stage 3 activities the school implementation carried out efforts to fulfill the quality in the form of workshop with inviting impact. The workshop material chosen was adjusted to the quality fulfillment plan.

Almost all schools had not been able to carry out monitoring and evaluation, especially when implementing a quality audit. Therefore, at the 6th stage of the meeting the school was directed to develop an evaluation instrument for 8 standards of national education and to practice implementing an internal quality audit. In general, not all schools were able to determine the indicators of success of activities starting from the process, output to the results of the implementation of quality fulfillment. Many schools also have not been able to analyze the implementation of quality fulfillment activities and compile quality compliance documents in the form of reports.

Product evaluation results and outputs, short and long term, intended and unintentional, which also focus to meet goals (Stufflebeam, 2003). The research findings (Table 7) showed that the results are all in the effective category. Community participation and stakeholders education component were increasing although not as much as the other components. The involvement of parents and the community component was getting higher because as all of them response positively to the idea of improving school quality services. The involvement of the local government was also higher, since government educational offices participated in opening activities and providing policy directions related to improving 
quality services in their regions in every school activities. The most increasing component was seen in the involvement of tertiary institutions and the partnership with business and industrial company. This increase occurred at some schools for example in Singaraja Middle School, Mengwi Middle School and Tri Atmajaya Vocational School. Other schools have planned activities to establish partnerships with companies and business and industrial company. In addition, the intensity of public complaints had also decreased and people's appreciation of the success of the schools has increased. Cooperation, openness, care and commitment among school members in supporting quality services were also increasing.

The quality learning process was also increasing. This was not only indicated by the increase in terms of gained scores and mastering competency but also in the quality of the observed teaching and learning process in the classroom. Almost all the observed model teachers had been able to apply the learning practices designed in the workshop so that learning was conducted effectively, efficiently and pleasantly especially with integrating effective media and learning resources. This is in accordance with the opinion by Sadler (2012: 201) who found that the problem of academic achievement standards in particular has significant implications in quality assurance. The discussion in his paper was on higher education but the principles also apply to other education sectors.

Furthermore, Aziz et al. (2018: 201-202) in its research findings state that it turns out that the Context, Input, Process and Product Evaluation (CIPP) model helps in evaluating the quality and accountability of education at the school level. This study considered to use the CIPP model to evaluate the implementation of SPMI because it can harmonize internal evaluations and external evaluations. Stufflebeam (1971) mentions that the CIPP evaluation model assists in internal / external evaluations, helps in evaluating the credibility and accountability of education, and assisting evaluators and staff in decision making. Without CIPP Model, errors, weaknesses or strengths of the internal quality assurance system cannot be highlighted which can reduce its effectiveness. The findings of this study indicated requirement for more resources, good environment, appropriate tools, effective communication and focus based on needs of all the beneficiaries involved. Previous research also emphasized that the most important thing to make better quality is to make efforts and to improve not just to prove (Stufflebeam\&Shinkfield, 2007). Likewise what was done in this study, before conducting the final evaluation, the researchers drafted the appropriate strategy given to each school according to their initial school evaluation. A study conducted on teacher service learning programs at the university and local schools (Zhang, Zeller, Griffith, Metcalf \& Williams, 2011) also supports the findings of this study regarding the use of the CIPP model to assess needs, formulate plans using input evaluation, monitor progress using process and input evaluations that used product evaluation. However, this study differs from previous studies in several aspects. In this study, the researchers started by conducting a study between the results of the initial evaluation with the achievement of school quality report cards. When the results showed that there was a discrepancy, the strategy was developed according to the conditions of the school. It is necessary to take steps to anticipate the problems that blocked the path to quality education and effective learning. This study can be a reference for future research in involving the CIPP evaluation model for evaluating the quality and development of school quality.

\section{Conclusions and Suggestions}

The purpose of this study was to measure the level of effectiveness of the implementation of internal quality Assurance System (SPMI) by using CIPP model after developing and implementing a companion strategy based on the results of the initial evaluation of the school model. For evaluation purposes, the CIPP Stufflebeam evaluation model was used to guide evaluation systematically by looking at various aspects of the quality of education in schools. According to various studies, the CIPP model was an effective model to improve and assess the quality from every angle. Many researchers applied this model to evaluate the quality of textbooks, curriculum and school evaluations. It included all goals, objectives, resources, environment, methodology, teaching and learning 
processes and school outcomes in the form of effective and successful learners (Scriven, 1973).

It can be concluded that the results of the implementation of internal quality Assurance System (SPMI) in the 2018 school model viewed from the aspect of context, input, process and results to be in effective, very effective and quite effective category. The level of evaluation in the context component: the preparation of the objectives of the 2018 Bali Quality Assurance Institution ( $L P M P$ Bali) school program was effective. It showed that most of the target schools have been able to arrange school programs according to the procedure. The level of evaluation in input component: the preparation of the organization of internal quality Assurance System (SPMI), policies and programs as well as the resources possessed regarding SPMI in schools, the Bali LPMP Model Year 2018 achieved very effective results. The level of evaluation in the components of the process of implementing $S P M I$ program in Bali's LPMP model: the process of mapping, planning, implementation of fulfillment, including effectiveness while evaluating the implementation was quite effective. The level of evaluation of the product components of the achievement of program implementation on increasing community participation as large as being quite effective increased the participation of school people and the competence of teachers and education personnel already effective.

This study can be a reference for future research studies on a systematic evaluation of internal quality Assurance System (SPMI) at the school level. This study aimed at evaluating the quality of education by applying the CIPP evaluation model. Through this research there are several recommendations given as follows.

1. For the Director General of Primary and Secondary Education, Ministry of Education and Culture, the results of this study are expected to be used as input for improving the technical guidance and School Assistance programs for the internal quality Assurance System according to the model proposed by Quality Assurance Institution throughout Indonesia. The results of this study implicates a more detailed and easier to implement the material for the study and development of operational and technical guidelines is required.

2. For Quality Assurance Institution, the results of this study can be used as information to help facilitators in solving problems and finding solutions to reduce problems that arise in mentoring SPMI model schools. The results of this study can be used as a source of information or reference in hopes of creating quality improvements both in the academic and school management side.

3. For the school model, it is expected that they get better service in the mentoring process, especially in the orientation of improving the quality of education in the education unit. The results of this study are input for school managers, so that the issuing policies to implement the education process in schools still refers to the National Education Standards. Specifically, it can be useful in an effort to improve the quality of the learning process, so that the quality management of the process of education is recognized by the community.

\section{References}

Almadani, Khaled. 2011. Quality assurance: a pressing problem for education In the 21st century. Problems of education in the 21st century. [Internet]. [diunduh 2018 April 2; Volume 32, 2011. Tersedia pada: http://www.scientiasocialis. It/pec/files/pdf/vol32/922.Almadani_Vol.32.pdf

Arikunto, Suharsimi dan Jabar CSA, 2008. Evaluasi Program Pendidikan, Jakarta : Bumi Aksara

Belas, Olga. et.al. 2015. Research on University Education Quality Assurance: methodologyand results of stakeholders' satisfaction monitoring. Procedia - Social and Behavioral Sciences. [Internet]. [diunduh 2018 April 2; Volume 214:344 - 358. Tersedia pada: https://creativecommons.org/licenses/by-nc-nd/4.0/

Darmawan. Jumlah sampel minimum?Analisis Korelasi Sederhana. Diakses Tanggal 2 April 2018. https://www.scribd.com/doc/136225933/Jumlah-Sampel-Minimum 
Dewi. 2011. Analisis Korelasi Sederhan. Diakses Tanggal 2 April 2018. http://duwiconsultant.blogspot.co.id/2011/11/analisis-korelasi-sederhana.html

D Royce Sadler. 2012. Assessment, evaluation and quality assurance: Implications for integrity in reporting academic achievement in higher education. Education Inquiry Vol. 3, No. 2, June 2012, pp.201-216. [Internet]. [diunduh 5 Mei 2019. Tersedia pada: www.researchgate.net/publication/26673]

De Grauwe, A., \& Naidoo J. P. 2004. School evaluation for quality improvement. International Institute for Educational Planning: UNESCO.

European Union. 2015. Comparative Study on Quality in EU School Education Systems Policies, procedures and practices. Final report DG EAC Order 12 Lot 3 DG EAC Framework Contract 4 June 2015[Internet]. [diunduh 2018 April 2. Tersedia pada:http://europa.eu

Haruthai Ajprua, et.al. 2014. Design of Educational Quality Assurance System for Driving Policy of Educational Reform in Thailand: Theory-based Evaluation. Procedia - Social and Behavioral Sciences ( 2014 ) 1416 - 1422. [Internet]. [diunduh 5 Mei 2019. Tersedia pada: www.sciencedirect.com]

Issac, Stephen and William B Michael. 1983. Handbook in Research and Evaluation. 2nd edition, San Diego: California, Edits Publisher.

Kaufman, Roger. and Susan Thomas, 1980. Evaluation Without Fear, London

Kemdikbud. 2017. Buku Pedoman 3 Petunjuk Pelaksanaan Penjaminan Mutu Pendidikan oleh Satuan Pendidikan: Jakarta

Koontz, Harold \& Heinz Weilrich. Management. Ninth Edition. Singapore: Irwin Mc Grow Hill International Edition, 1988.

Madaus, G.F., Scriven, M.S., \& Stufflebeam, D.L. (1993). Evaluation models,viewpoints on educational and human services evaluation. Boston:Kluwer-Nijhoff Publishing.

Scriven, M. (1973). Goal-free evaluation. In E. R. House (Ed.). School evaluation (pp. 319328). Berkeley: McCutchan.

Shamsa Aziz, et.al. 2018. Implementation of CIPP Model for Quality Evaluation at School Level: A Case Study. Journal of Education and Educational Development Vol. 5 No. 1. [Internet]. [diunduh 5 Mei 2019. Tersedia pada: https://files.eric.ed.gov/ fulltext/ EJ1180614.pdf]

Stake, Robert E. 2006. The Countenance of Educational Evaluation, Center for Instructional Research and Curriculum Evaluation, Paper University of Illinois.

Stufflebeam, D. L. (1969). Evaluation as enlightenment for decision making improving educational assessment \& an inventory of measures of affective behavior, edited by Walcott H. Beatty (pp. 41-73).Washington, D.C: The Association for Supervision and Curriculum Development, NEA.

Stufflebeam, Daniel L \& Antohony J. Shinkfield. Systematic Evaluation, A Self-Instructional Guide to Theory and practice. Boston: Kluwer-Nijhoff Publishing, 1986.

Stufflebeam, D.L., \& Shinfield, A.J. 1985. Systematic evaluation. Boston: Kluwer Nijhof Publishing.

Stufflebeam, D.L. (2000). The CIPP model for evaluation. In Stufflebeam, D.L., Madaus, G.F. Kellaghan, T. (Eds). Evaluation models. Viewpoints on educational and human service evaluation. (pp. 279-317). (2nd ed). Boston: Kluwer Academic.

Stufflebeam, D. L. (2002a). CIPP evaluation checklist. A tool for applying the fifth installment of the CIPP model to assess long-term enterprises. Retrieved from http://www.wmich.edu/evalctr/checklists/cippchecklist.htm

Stufflebeam, D. L. (2002b). The CIPP model for evaluation. In D.L. Stufflebeam, C.F. Madam \& T. Kellaghan (Eds.), Evaluation models (pp. 279-317). New York: Kluwer Academic Publishers. Vol. 5 No. 1 (June 2018) CIPP Model for Quality Evaluation 206.

Stufflebeam, D. L. (2003). The CIPP model for evaluation. In D. L. Stufflebeam \& T. Kellaghan (Eds.), The international handbook of educational evaluation (Chapter 2). Boston, MA: Kluwer Academic Publishers. 
Stufflebeam, D. L., \& Shinkfield, A. J. (2007). Evaluation theory, models, \& applications. San Francisco, CA: Jossey-Bass. Thorndike, R. L., (1969); Perspectives in educational and psychological measurement. New York: Prentice-Hall, Englewood Cliffs.

Undang-Undang RI Nomor 20 Tahun 2003 Tentang Sistem Pendidikan Nasional.

Zhang, G., Zeller, N., Griffith, R., Metcalf, D., \& Williams, J. (2011). Using the context, input, process and product evaluation model (CIPP) as a comprehensive framework to guide the planning, implementation and assessment of service-learning. Journal of Higher Education Outreach and Engagement, 15(4) 57. 